\title{
Analisis usaha mikro kecil dan menengah (UMKM) pada pondok pesentren di Kota Jambi
}

\author{
Avrizal*; Haryadi; Syurya Hidayat \\ Prodi Magister Ilmu Ekonomi Program Pascasarjana Universitas Jambi \\ *E-mail. korespondesi : rizal.scout27@gmail.com
}

\begin{abstract}
This study aims to find out how the socioeconomic characteristics of MSMEs in Islamic boarding schools and what factors affect MSME income and what strategies to develop MSMEs at Islamic boarding schools. This research uses qualitative and quantitative approaches. The data used are primary data, a sample of 73 respondents. The respondents consisted of SMEs who were in the boarding school environment. Data collection was carried out through surveys and interviews using a questionnaire that was distributed to respondents. Data were analyzed using multiple regression analysis (multiple regression). The results showed that the variable fixed capital, operational capital and working hours significantly influence the income of UMKM traders in pesentren while the length of business and location variables did not significantly influence the income of UMKM traders in pondok pesentren.
\end{abstract}

Keywords : Fixed capital, Operational capital, Working hours, Length of business, Location effort, multiple regression.

\begin{abstract}
Abstrak
Penelitian ini bertujuan untuk mengetahui bagaimana karakteristik sosial ekonomi UMKM pada pondok pesantren dan faktor - faktor apa saja yang mempengaruhi pendapatan UMKM serta strategi apa saja untuk mengembangkan UMKM pada Pondok pesantren. Penelitian ini menggunakan pendekatan kualitatif dan kuantitatif. Data yang digunakan adalah data primer, sampel sebanyak 73 responden. Responden tersebut terdiri para pelaku UMKM yang berada didaerah lingkungan pondok pesantren. Pengumpulan data dilakukan melalui survey dan wawancara dengan menggunakan kuesioner yang dibagikan kepada responden. Data dianalisis dengan menggunakan analisis multiple regression (regresi berganda). Hasil penelitian menunjukkan bahwa variabel modal tetap, modal operasional dan jam kerja berpengaruh signifikan terhadap pendapatan pedagang UMKM pondok pesentren sedangkan variabel lama usaha dan lokasi tidak berpengaruh signifikan terhadap pendapatan pedagang UMKM di pondok pesentren.
\end{abstract}

\footnotetext{
Kata kunci : Modal tetap, Modal Operasional, Jam kerja, Lama usaha, Lokasi usaha, Regresi berganda.
}

\section{PENDAHULUAN}

Pengembangan Usaha Mikro dan Kecil (UMK) di Indonesia merupakan salah satu prioritas dalam pembangunan ekonomi nasional. Hal ini selain karena usaha tersebut merupakan tulang punggung sistem ekonomi kerakyatan yang tidak hanya ditujukan untuk mengurangi masalah kesenjangan antar golongan pendapatan dan antar pelaku 
usaha, ataupun pengentasan kemiskinan dan penyerapan tenaga kerja. Lebih dari itu, pengembangannya mampu memperluas basis ekonomi dan dapat memberikan konstribusi yang signifikan dalam mempercepat perubahan struktural, yaitu meningkatnya perekonomian daerah dan ketahanan ekonomi nasional (Boediono, 2009).

Program dan kegiatan yang dilakukan pemerintah dalam upaya mengembangkan sektor Usaha Mikro dan Kecil (UMK) selama ini sungguh menggembirakan. Peningkatan peran dan kegiatan usaha sektor ini semakin nampak khususnya sejak era krisis ekonomi dan keuangan pada tahun 1997. Ditengah-tengah proses restrukturisasi sektor korporat dan BUMN yang berlangsung lamban, sektor ini telah menunjukkan perkembangan yang terus meningkat dan bahkan mampu menjadi penopang pertumbuhan ekonomi nasional.

Pengembangan Usaha Mikro dan Kecil merupakan bagian yang terintegrasi dalam program pengembangan Usaha Kecil dan Menengah (UKM), kegiatan pengembangannya ditujukan sebagai salah satu pilar ekonomi kerakyatan yang dapat menjadi penggerak utama perekonomian daerah (Boediono, 2009).

Usaha Mikro mempunyai peran yang sangat strategis dalam pengembangan ekonomi nasional, efek yang bersifat usaha rakyat dimaksud berperan penting dalam pertumbuhan ekonomi dan penyerapan tenaga kerja juga berperan dalam mendistribusikan hasil-hasil pembangunan. Usaha mikro merupakan basis usaha rakyat, yang secara mengejutkan mampu bertahan di masa krisis 1997/1998. Di sisi lain, jatuhnya sebagian usaha - usaha besar dan menengah serta adanya keterbatasan yang dimiliki tenaga kerja menjadi momentum bagi perubahan struktur ekonomi yang berorientasi pada usaha kecil.

Sektor usaha kecil merupakan sektor yang masih bertahan ditengah-tengah krisis ekonomi dan perlu untuk dikembangkan, karena sektor industri kecil merupakan usaha yang bersifat padat karya, tidak membutuhkan persyaratan tertentu seperti tingkat pendidikan, keahlian (keterampilan) pekerja dan penggunaan modal usaha relatif sedikit serta teknologi yang digunakan cenderung sederhana (Kasal, 2010).

Kondisi saat ini UMKM juga sudah dijalankan pada lembaga pendidikan seperti Pesantren, Pesantren menjadi pendidikan alternatif dan bukan pilihan utama, tetapi memiliki potensi yang mampu bangkit menepis stigma negatif dengan keinginan yang kuat, kemampuan, dan bekerjasama dengan masyarakat melakukan program pemberdayaan yang berhasil membentuk kelompok usaha dan Koperasi Syariah. Menurut Ade (2009) ekonomi syariah sebagai solusi alternatif sistem ekonomi yang menjalankan kegiatan ekonomi dengan menjunjung tinggi nilai - nilai kepemilikan, nilai-nilai keadilan, kebebasan, keseimbangan dan persaudaraan serta kebersamaan. AlHamdani (2005) menyatakan pesantren merupakan institusi keagamaan yang tidak mungkin bisa dilepaskan dari masyarakat, khususnya masyarakat pedesaan, karena pesantren tumbuh dan berkembang dari dan untuk masyarakat. Daniar (2013) menegaskan bahwa pondok pesantren memiliki peran yang sangat strategis yaitu sebagai pusat pengembangan agama, pendidikan, sosial dan budaya serta sebagai kekuatan ekonomi.

Dengan demikian pesantren menjadi bagian penting dalam pengembangan lembaga pendidikan baik sosial maupun ekonomi dan agama (moral) yang mampu menjawab tuntutan serta tantangan jaman yang semakin berkembang. Terdapat relevansi pesantren dengan pendidikan nasional termaktub dalam Undang-Undang Nomor 20 tahun 2003 tentang Sistem Pendidikan Nasional, Pasal 3 yaitu Pendidikan nasional berfungsi mengembangkan kemampuan dan membentuk watak serta peradaban 
bangsa yang bermartabat dalam rangka mencerdaskan kehidupan bangsa, bertujuan untuk berkembangnya potensi peserta didik agar menjadi manusia yang beriman dan bertakwa kepada Tuhan Yang Maha Esa, berakhlak mulia, sehat, berilmu, cakap, kreatif, mandiri, dan menjadi warga negara yang demokratis serta bertanggung jawab.

Berdasarkan tantangan dan tuntutan globalisasi tersebut, maka pesantren memiliki potensi dan kemampuan melakukan pendidikan (1) Pembentukan karakter menjadi insan yang beriman dan bermoral untuk menangkal dampak negatif globalisasi terutama pengaruh negatif teknologi media informasi seperti pornografi yang mengarah pada pornoaksi atau tindakan pelanggaran moral dan hukum. Ubaidillah (2006) berpendapat bahwa globalisasi dan kebudayaan asing telah masuk dalam masyarakat, dampaknya banyak generasi muda kita yang terjerumus dalam kebudayaan asing yang negatif seperti pergaulan bebas dan lain-lain, sehingga peran pesantren dalam membentengi generasi muda kita dari serangan globalisasi masih sangat dibutuhkan.

Pondok pesentren merupakan pendidikan non formal yang tersebar diseluruh Indonesia. Seiring dengan perkembangan zaman pondok pesantren telah berkembang pesat menjadi salah satu lembaga pendidikan yang berperan aktif dalam meluluskan santri-santri yang berprestasi dan juga beraklaqul Kharimah. Pondok pesantren berperan aktif dilingkungan dikarenakan adanya seorang kiyai yang menjadi suri tauladan atau dijadikan tokoh sentral dalam masalah-masalah agama tak hanya itu dipondok pesantren pula dapat membantu lingkungan di sekitarnya dalam kehidupan sehari-hari dan juga kebutuhan sehari-hari santrinya dalam hal jual beli. Bukti nyata atas suksesnya pondok pesantren dalam ranah ekonomi adalahnya berdirinya Usaha Mikro Kecil Menengah (UMKM) di lingkungan Pesentren di Kota Jambi.

\section{METODE}

\section{Rancangan penelitian}

Untuk memperoleh data yang representatif digunakan metode pengumpulan data: 1).Penelitian Lapangan (Field Reseacrh) dimana penelitian lapangan ini dilakukan untuk mendapatkan data premier, guna memperoleh gambaran secara objektif terhadap objek yang akan diteliti. Adapun teknik pengambilan data yang dilakukan dengan Observasi dan Interview. 2).Penelitian Kepustakaan (Library Research) dimana dalam metode pengumpulan data ini penulis mempelajari berbagai literatur, seperti buku-buku, majalah dan sumber-sumber bacaan lainnya yang mendukung penelitian ini.

\section{Lokasi dan waktu penelitian}

Penelitian dilakukan pada 17 Pondok Pesantren di Kota Jambi. Waktu penelitian direncanakan akan dilaksanakan pada bulan Januari dan Februai tahun 2020.

\section{Populasi dan sampel}

Populasi adalah wilayah generalisasi yang terdiri atas objek atau subjek yang mempunyai kualitas dan karakteristik tertentu yang ditetapkan oleh peneliti untuk dipelajari dan kemudian ditarik kesimpulanya. Jadi populasi sebenarnya bukan hanya orang tetapi juga objek atau subjek beserta karakteristik atau sifat-sifatnya. Dalam penelitian ini, populasi yang digunakan adalah Jumlah pedagang UMKM pada pondok Pesentren di Kota Jambi. Populasi tersebut berjumlah 73 pedagang yang dilihat berdasarkan jumlah unit mengingat jumlah populasi sangat kecil, maka populasi sekaligus ditetapkan sebagai sampel. 


\section{Jenis dan sumber data}

Jenis data yang digunakan dalam penilitian ini adalah data kualitatif dan kuantitatif, sumbernya adalah data primer dan data sekunder. Pengumpulan data dilakukan melalui survey dan wawancara dengan menyebarkan kuesioner yang didistribusikan secara langsung sendiri oleh peneliti kepada pelaku usaha yang berada di Pondok Pesantren di Kota Jambi.

\section{Metode analisis data}

Statistik deskriptif digunakan dalam penelitian ini untuk memberikan jawaban tentang karakteristik sosial ekonomi pedagang UMKM yaitu berupa pemaparan atau penggambaran dengan kata-kata secara jelas dan terperinci(KKBI,2001).

Untuk menjawab permasalahan kedua yaitu faktor-faktor yang mempengaruhi pendapatan UMKM pada pondok pesantren maka digunakan model analisis regresi linear berganda dan mengolah hasilnya dengan aplikasi eviwes. SWOT.

Menjawab permasalahan ketiga dalam penelitian ini menggunakan analisis

\section{Pengujian hipotesis}

\section{Uji-F}

Uji $\mathrm{F}$ digunakan untuk mengetahui tingkat signifikan antara variable independen terhadap variable dependen secara serempak. Pengujian tersebut dilakukan dengan membandingkan nilai F-hitung dengan F-tabel. Dengan menggunakan taraf signifikasi $5 \%$ atau 0,05 dengan criteria Jika $\mathrm{F}$ hitung $>\mathrm{F}$ table maka pengaruh simultan variable independent terhadap variabel dependent dan Jika F hitung $<\mathrm{F}$ table maka tidak terdapat pengaruh simultan.

\section{Uji-t}

Uji-t adalah jenis pengujian statistik untuk mengetahui apakah ada perbedaan dari nilai yang diperkirakan dengan nilai hasil perhitungan statistik. Uji t pada dasarnya menunjukan seberapa jauh pengaruh satu variabel bebas secara individual dalam menerangkan variasi terikat. Uji t menilai apakah mean dan keragaman dari dua kelompok berbeda seca statistic satu sama lainya.

\section{Koefisien determinasi}

Uji koefisien determinasi digunakan untuk mengukur seberapa besar presentase variasi variabel bebas (independen) pada model regeresi linier berganda dalam menjelaskan variabel terikat (dependen) (Priyantno,2008). Nilai koefisien determinasi adalah antara nol dan satu. Nilai $\mathrm{R}^{2}$ yang kecil bearti kemampuan variabel-variabel independen dalam menjelasakan variabel dependen amat terbatas. Nilai yang mendekati satu bearti variabel-variabel independen memberikan hampir semua informasi yang dibutuhkan untuk memprediksi variasi variabel dependen (Augusty Ferdinanda,2006).

\section{Uji asumsi klasik}

\section{Uji normalitas}

Uji normalitas bertujuan untuk menguji apakah model regresi, variabel terikat, variabel bebas atau keduanya mempunyai distribusi normal atau tidak. Model regresi yang baik adalah memiliki distribusi data normal atau penyebaran data statistika pada sumbuh diagonal dari grafik distribusi normal (Ghozali,2001). 
Pengujian normalitas dalam penelitian ini digunakan dengan melihat normal probabilityplot yang membandingkan distribusi kumulatif dari data sesungguhnya dengan distribusi kumulatif dari data normal. Sedangkan dasar pengambilan keputusan untuk uji normalitas data adalah (Ghozali,2001).

\section{Uji heterokedasitas}

Uji Heterokedasitas bertujuan untuk menguji apakah dalam model regresi terjadi ketidaksamaan Variance dari residual suatu pengamatan ke pengamatan lainya. Jika variance dari pengamatan satu kepengamatan lainya tetap, maka tidak terjadi heterokedasitas, atau terjadi homokedastisitas adalah dengan membuat grafik plot.

\section{Uji autokorelasi}

Autokorelasi adalah korelasi yang terjadi di antara anggota-anggota dari serangkaian pengamatan yang tersusun dalam rangkaia waktu (Ernawati,dkk,2005). Menurut Ghozali (2006), Uji autokolerasi bertujan untuk menguji apakah dalam model regresi linear ada kolerasi antara kesalahan penganggu pada periode $t$ dengan kesalahan penganggu pada periode t-1 (sebelumnya). Mengetahui hal tersebut, dapat digunakan $u j i$ run test.

\section{Uji multikolinearitas}

Ghozali (2006) mendefinisikan multikolinearitas sebagai suatu situasi adanya kolerasi variabel-variabel independen diantara satu dan yang lainnya ada tidaknya multikolinearitas antara variabel independen dilihat dari nilai tolerance dan lawannya variance inflation faktor (VIF). Kedua ukuran ini menunjukan setiap variabel independen manakah yang dijelaskan variabel independen lainya. Tolerance mengukur variabilitas variabel independen yang terpilih yang tidak dijelaskan variabel independen lainya. Nilai cutoff untuk menunjukan adanya multikolineritas adalah nilai tolerance < 0,05 atau sama dengan nila VIF > 5 (Ghozali,2006).

\section{HASIL DAN PEMBAHASAN}

\section{Karakteristik responden berdasarkan umur}

Sebelum mengetahui karakteristik responden berdasarkan umur, terlebih dahulu dilakukan perhitungan skala interval dengan umur responden termuda 20 tahun dan umur responden paling tua berumur 66 tahun. Range dari umur 31 tahun ke 66 tahun adalah 36 tahun, jika di penelitian ini menggunakan 4 kali interval, maka jarak setiap interval adalah $36: 4=9$. Artiya jarak interval katagori umur responden adalah 9 tahun.

Tabel 1. Karakteristik responden berdasarkan umur

\begin{tabular}{cccc}
\hline No & Umur & Frekuensi & Persentase $(\boldsymbol{\%})$ \\
\hline 1 & 31-39 Tahun & 17 & 23,29 \\
2 & 40-48 Tahun & 25 & 34,25 \\
3 & 49-57 Tahun & 19 & 26,03 \\
4 & 58-66 Tahun & 12 & 16,43 \\
\hline & Jumlah & $\mathbf{7 3}$ & $\mathbf{1 0 0 , 0 0}$ \\
\hline
\end{tabular}

Sumber : Data diolah 2020 
Dari Tabel 1 di atas dapat dilihat bahwa jumlah Pedagang UMKM pondok pesentren berdasarkan tingkat umur yaitu pedagang berusia 31-29 tahun sebanyak 17 orang dengan persentase 23,29 persen. Kemudian pedagang yang berusia 40-48 tahun sebanyak 25 orang dengan persentase 34,25 pedagang yang berusia 49-57 tahun sebanyak 19 orang dengan persentase 26,03 persen, pedagang yang berusia 58-66 tahun hanya sebanyak 12 orang dengan persentase 16,43 persen. Berdasarkan hasil tersebut, dapat dikatakan bahwa rata-rata umur pedagang UMKM di pondok pesentren berkisar 40-48 tahun, di umur ini dapat dikatakan sangat efektif dan efisien untuk mencari penghasilan dan dimana pada masa ini seseorang telah mempunyai banyak pengalaman sehingga dapat mengatasi masalah-masalah yang muncul. Sementara untuk pedangan UMKM di pondok pesentren berusia 58-66 tahun hanya 6 orang dikarenakan pada umur ini pedagang sudah mulai termakan oleh usia dan tidak mampu untuk bekerja lebih keras lagi disebabkan oleh fisik yang sudah melemah.

\section{Karakteristik Responden Berdasarkan Jumlah Anak}

Banyaknya responden dalam penelitian ini yaitu pedagang UMKM pondok pesentren di Kota Jambi menurut Jumlah anak yang dapat dilihat pada tabel berikut :

Tabel 2. Karakteristik responden berdasarkan jumlah anak

\begin{tabular}{cccc}
\hline No & Jumlah Anak & Frekuensi & Persentase (\%) \\
\hline 1 & Tidak Ada & 2 & 2,74 \\
2 & 1 & 15 & 20,55 \\
3 & 2 & 33 & 42,20 \\
4 & $>3$ & 23 & 31,50 \\
\hline & Jumlah & $\mathbf{7 3}$ & $\mathbf{1 0 0 , 0 0}$ \\
\hline
\end{tabular}

Sumber : Data diolah 2020

Dari Tabel 2 di atas dapat dilihat bahwa jumlah pedagang UMKM di pondok pesentren yang tidak mempunyai anak sebanyak 2 orang dengan persentase 2,74 persen, pedagang yang mempunyai 1 orang anak sebanyak 15 orang dengan persentase sebesar 20,55 persen, pedagang yang mempunyai 2 orang anak sebanyak 33 orang dengan persentase 42,20 persen, sedangkan pedangan yang mempunyai 3 orang anak atau lebih sebanyak 23 orang dengan persentase 31,50 persen. Berdasarkan hasil tersebut, dapat dikatakan bahwa rata-rata jumlah anak pedagang UMKM di pondok pesantren Kota Jambi berkisar 2 orang anak, sedikitnya jumlah anak pada responden penelitian ini dikarenakan disat pedagang sudah mulai usaha, ada kekurangan keinginan untuk mempunyai anak lagi karena pedagang sangat focus untuk berdagang walapun jumlah anak tersebut menjadi motivasi pedangan UMKM di pondok pesantren untuk meningkatkan pendapatan. Sedangkan responden yang tidak satupun mempunyai anak hanya 2 orang dengan frekuensi 2,74 persen, ini membuktikan bahwa anak menjadi alasan pedagang untuk melakukan kegiatan usaha agar mendapatakan penghasilan.

\section{Karakteristik responden berdasarkan jumlah tanggungan}

Banyaknya responden dalam penelitian ini yaitu pedangang UMKM di pondok pesantren Kota Jambi menurut jumlah tangunggan yang dapat dilihat pada tabel berikut ini: 
Tabel 3. Karakteristik responden berdasarkan jumlah tangunggan

\begin{tabular}{cccc}
\hline No & Jumlah tanggungan & Frekuensi & Persentase (\%) \\
\hline 1 & Tidak Ada & 2 & 2,73 \\
2 & 1 & 8 & 10,95 \\
3 & 2 & 24 & 32,87 \\
4 & $>3$ & 39 & 53,42 \\
\hline & Jumlah & $\mathbf{7 3}$ & $\mathbf{1 0 0 , 0 0}$ \\
\hline
\end{tabular}

Sumber : Data diolah 2020

Dari Tabel 3 di atas dapat dilihat bahwa jumlah pedagang UMKM di pondok pesentren Kota Jambi yang tidak mempunyai tangunggan sebanyak 2 orang dengan persentase 2,73 persen, pedagang yang mempunyai 1 orang tangunggan sebanyak 8 orang dengan persentase sebesar 10,95 persen, pedangan yang mempunyai 2 orang tangunggan sebanyak 24orang dengan persentase 32,87 persen, sedangkan pedagang yang mempunyai 39 orang tangunggan atau lebih sebanyak 29 orang daengan persentase 54,32 Persen. Berdasarkan hasil tersebut, dapat dikatakan bahwa rata-rata jumlah tangunggan pedagang usaha UMKM berkisar 3 orang tangunggan. Besarnya jumlah tangunggan akan meningkatkan motivasi pedagang UMKM untuk meningkatkan pendapatanya. Hal ini dibuktikan jumlah responden terbanyak berdasarkan jumlah taggungan adalah 3 orang atau lebih dengan responden sebanyak 39 orang sementara sebaliknya jumlah responden terendah berdasarkan jumlah tanggungan yaitu tidak ada tanggungan dengan jumlah responden sejumlah 2 orang.

\section{Karakteristik responden berdasarkan tingkat pendidikan}

Banyaknya responden dalam penelitian ini yaitu pedagang UMKM di pondok pesentren Kota Jambi menurut tingkat pendidikan yang dapat dilihat pada tabel berikut:

Tabel 4. Karakteristik responden berdasarkan tingkat pendidikan

\begin{tabular}{clcc}
\hline No & Tingkat Pendidikan & Frekuensi & Persentase (\%) \\
\hline 1 & Sekolah Menengah Pertama & 5 & 6,84 \\
2 & Sekolah Menengah Atas & 9 & 12,32 \\
3 & Diploma II-Diploma IV & 25 & 34,24 \\
4 & Strata I - Strata II & 34 & 46,57 \\
\hline & Jumlah & $\mathbf{7 3}$ & $\mathbf{1 0 0 , 0 0}$ \\
\hline
\end{tabular}

Sumber : Data diolah 2020

Dari Tabel 4 dapat dilihat bahwa jumlah pedagang UMKM di pondok pesentren Kota Jambi yang mempunyai tamatan pendidikan jenjang Sekolah Menengah Pertama aebanyak 5 orang dengan persentase 6,84 persen, pedang UMKM yang mempunyai tamatan pendidikan Sekolah Menengah Atas sebanyak 9 orang dengan persentase 12,32 persen, pedagang UMKM yang mempunyai tamatan pendidikan jenjang Diloma IIDiploma IV sebanyak 25 orang dengan persentase 34,24 persen, sedangkan pedagang UMKM yang mempunyai pendidikan Jenjang Strata 1 - Strata II sebanyak 34 orang dengan persentase sebesar 46,57 persen. Bersadarkan hasil tersebut, dapat dikatakan bahwa rata-rata tingkat pendidikan pedagang UMKM yaitu tamatan Strata I-Strata II. Tingginya tingkat pendidikan akan meningkatkan kualitas SDM seorang pedagang sehingga dapat meningkatkan daya saing dalam persaingan ketat antar pedagang UMKM. 


\section{Karakteristik responden berdasarkan jam kerja}

Sebelum mengetahui karakteristik responden berdasarkan jam kerja, terlebih dahulu dilakukan perhitungan skala interval jam kerja dengan jam kerja responden tercepat yaitu 7 jam dan jam kerja terlama responden 14 jam. Range dari 7 jam ke 14 jam adalah 8 jam. Jika penelitiam ini menggunakan 4 kali interval maka jarak setiap interval adalag 8:4=2, artinya jarak interval katagori jam kerja responden adalah 2 jam.

Tabel 5. Karakteristik responden berdasarkan jam kerja

\begin{tabular}{cccc}
\hline No & Jam Kerja & Frekuensi & Persentase (\%) \\
\hline 1 & $7-8$ Jam & 13 & 18,80 \\
2 & $9-10 \mathrm{Jam}$ & 28 & 38,35 \\
3 & $11-12 \mathrm{Jam}$ & 31 & 42,46 \\
4 & $13-14 \mathrm{Jam}$ & 1 & 1,36 \\
\hline & Jumlah & $\mathbf{7 3}$ & $\mathbf{1 0 0 , 0 0}$ \\
\hline
\end{tabular}

Sumber : Data diolah 2020

Dari Tabel 5 dapat dilihat bahwa pedagang UMKM di Kota Jambi yang bekerja selama 7 sampai 6 jam terdapat 13 pedagang dengan persentase sebesar 18,80 persen, yang bekerja selama 9 sampai 10 jam terapat 28 pedagang dengan persentase sebanyak 38,35 persen. Kemudian yang bekerja selama lebih dari 11 sampai 12 jam yaitu 31 orang dengan persentase 42,46 persen, sedangkan yang bekerja selama 13 sampai 14 jam yaitu hanya 1 orang dengan persentase 1,36 persen. Bedasarkan hasil tersebut dapat dilihat bahwa rata-rata jam kerja pedangang UMKM pondok pesentren di Kota Jambi sebesar 11 sampai 12 jam bekerja dan hasil tersebut sesuai dengan waktu ideal bagi pedagang untuk bekerja. Lamanya jam bekerja tersebut tentunya akan meningkatkan dan memaksimalkan pendapatan pedagang UMKM di pondok pesentren.

\section{Karakteristik responden berdasarkan lama usaha}

Sebelum mengetahui karakteristik responden berdasarkan lama usaha, terlebih dahulu dilakukan perhitungan skala interval lama usaha dengan lam usaha responden dari tahun sampai 20 tahun. Range dari 1 tahun ke 20 tahun adalah 20 tahun. Jika di penelitian ini menggunakan 4 kali interval, maka jarak setiap interval adalah 20:4 $=5$. Artinya jarak interval katagori lama usaha responden adalah 5 tahun.

Tabel 6. Karakteristik responden berdasarkan lama usaha

\begin{tabular}{cccc}
\hline No & Lama Usaha & Frekuensi & Persentase (\%) \\
\hline 1 & 1-5 Tahun & 6 & 8,21 \\
2 & 6-10 Tahun & 22 & 30,13 \\
3 & 11-15 Tahun & 31 & 43,46 \\
4 & 16-20 Tahun & 14 & 19,17 \\
\hline & Jumlah & $\mathbf{7 3}$ & $\mathbf{1 0 0 , 0 0}$
\end{tabular}

Sumber : Data diolah 2020

Dari Tabel 6 dapat dilihat bahwa pedangan UMKM pondok Pesentren di Kota Jambi yang lama usahanya mencapai 1 sampai 5 tahun terdapat 6 pedangang dengan persentase sebesar 8,21 persen, lama usaha 6-10 tahun sebanyak 22 pedangan dengan persentase sebesar 30,13 persen, lama usaha 11 sampai 15 tahun dengan jumlah sebesar 31 pedangan dengan persentase sebesar 43,46 persen, dan lama usaha 16 sampai 20 tahun sebanyak 14 persen dengan persentase 19,17 persen. Bedasarkan hasil tersebut dapat dilihat bahwa rata-rata lama usaha UMKM di pondok pesentren Kota Jambi 
selama 11 sampai 15 tahun bekerja. Hal ini dikarenakan UMKM di pondok pesentren mulai berkembang dalam 10 tahun terakhir hamper disemua pondok pesentren Kota Jambi sudah banyak berdiri unit-unit usaha seperti ketring, mini market, laundry, koperasi, depot air minum dll,pondok pesentren ini juga diyakini memiliki potensi dalam mendorong pertumbuhan ekonomi.

\section{Karakteristik responden berdasarkan lokasi usaha}

Banyak responden dalam penelitian ini yaitu pedangan UMKM pondok pesentren Kota Jambi menurut lokasi yang dapat dilihat pada tabel berikut :

Tabel 7. Karakteristik responden berdasarkan lokasi usaha

\begin{tabular}{clcc}
\hline No & \multicolumn{1}{c}{ Lokasi } & Frekuensi & Persentase (\%) \\
\hline 1 & Strategis & 56 & 76,71 \\
2 & Tidak strategis & 17 & 23,28 \\
\hline & Jumlah & $\mathbf{7 3}$ & $\mathbf{1 0 0 , 0 0}$
\end{tabular}

Sumber : Data diolah 2020

Dari Tabel 7 dapat dilihat bahwa pedagang UMKM di Kota Jambi yang berjualan di lokasi strategis terdapat 56 pedangan dengan persentase sebesar 76,71persen, sementara pedangan UMKM pondok pesentren Kota Jambi yang berjualan di lokasi tidak strategis 17 pedagang dengan persentase sebesar 23,28 persen. Berdasakan hasil tersebut dapat dilihat bahwa sangat banyak pedagang berjualan di tempat yang strategis. Hal ini dikarenakan berjualan ditempat yang strategis akan meningkatkan jumlah pembeli sehingga omset dan pendapatan akan ikut meningkat.

\section{Karakteristik Responden Berdasarkan Omset}

Sebelum mengethaui karakteristik responden berdasarkan omset, terlebih dahulu dilakukan perhitungan skala interval omset dengan omset responden dari omset terkecil yaitu Rp 200.000 sampai Rp. 2.500.000 Range dari Rp. 200.000 interval ke Rp. 2.500.000 adalah Rp. 2.400.000. Jika di penelitian ini menggunakan kali interval, maka jarak setiap interval adalah Rp. $2.400 .000: 4=$ Rp. 600.000. Artinya jarak interval katagori omset Responden adalah Rp. 600.000

Tabel 8 Karakteristik responden berdasarkan omset

\begin{tabular}{clcc}
\hline No & \multicolumn{1}{c}{ Omset } & Frekuensi & persentase (\%) \\
\hline 1 & Rp 200.000 - Rp 700.000 & 20 & 27,40 \\
2 & Rp 800.000 - Rp. 1.300.000 & 41 & 56,16 \\
3 & Rp.1.400.000 - Rp. 1.900.000 & 10 & 13,70 \\
4 & Rp. 2.000.000 - Rp. 2.500.000 & 2 & 2,47 \\
\hline \multicolumn{2}{c}{ Jumlah } & $\mathbf{7 3}$ & $\mathbf{1 0 0 , 0 0}$ \\
\hline
\end{tabular}

Sumber : Data diolah 2020

Dari Tabel 8 dapat dilihat bahwa pedagang UMKM di pondok pesentren Kota Jambi yang omsetnya berkisar Rp.200.000 sampai Rp. 700.000 perharinya sebanyak 20 orang pedagang dengan persentase sebesar 27,40 persen, kemudian jumlah pedagang UMKM pondok pesentren Kota Jambi yang omset perharinya diantara RP.800.000 sampai dengan Rp. 1.300.000 yaitu sebanyak 41 pedagang dengan persentase sebesar 56,16 persen, omset berkisar Rp.1.400.000 sampai Rp. 1.900 .000 perharinya sebanyak 10orang dengan persentase sebesar 13,70 persen, sementara omset berkisar Rp. 2.000.000 sampai Rp. 2.500 .000 perharinya hanya sebanyak 2 orang dengan persentase sebesar 2,47 persen. Jumlah omset dengan jumlah pedagang terbanyak yaitu omset Rp. 
800.000 sampai dengan Rp. 1.300.000 dengan jumlah pedagang sebanyak 41 orang. Hal tersebut disebabkan omset Rp.800.000 sampai dengan Rp.1.300.000 merupakan omset yang ideal yang didapat setiap harinya oleh pedagang UMKM pondok pesentren didalam omset tersebut sudah termasuk modal operasional, biaya operasional dan laba.

\section{Karakteristik responden berdasarkan modal tetap}

Sebelum mengethaui karakteristik responden berdasarkan modal tetap, terlebih dahulu dilakukan perhitungan skala interval modal tetap dengan modal tetap responden dari yang terkecil yaitu Rp. 4.000.000 sampai Rp. 30.000.000 Range dari Rp. 4.000.000 ke Rp. 30.000.000 adalah Rp. 27.000.000. jika di penelitian ini menggunakan 3 kali interval, maka jarak setiap interval adalah Rp.27.000.000:3 = Rp. 9.000.000. Artinya jarak interval katagori modal tetap responden adalah Rp. 9.000.000.-

Tabel 9. Karakteristik responden berdasarkan modal tetap

\begin{tabular}{cccc}
\hline No & Modal Tetap & Frekuensi & Persentase (\%) \\
\hline 1 & Rp. 4.000.000 - Rp.12.000.000 & 38 & 52,05 \\
2 & Rp. 13.000.000 - Rp. 21.000 .000 & 33 & 45,21 \\
3 & Rp. 22.000.000 - Rp.30.000.000 & 2 & 2,74 \\
\hline \multicolumn{2}{c}{ Jumlah } & $\mathbf{7 3}$ & $\mathbf{1 0 0 , 0 0}$ \\
\hline
\end{tabular}

Sumber : Data diolah 2020

Dari Tabel 9 dapat dilihat bahwa pedagang UMKM di pondok pesentren di Kota Jambi yang modal tetapnya berkisar Rp. 4.000.000 - Rp. 12.000 .000 sebanyak 38 orang pedagang dengan persentase 52,05 persen, kemudian jumlah pedagang yang modal tetapnya diantara Rp. 13.000.000 sampai Rp. 21.000.000 yaitu sebanyak 33 pedagang dengan persentase sebesar 45,21 persen, sedangkan modal tetap berkisar Rp. 22.000 .00 sampai Rp. 30.000.000 sebanyak 2 orang atau 2,74 persen. Modal tetap dengan jumlah pedagang paling banyak yaitu modal tetap berkisar Rp.4.000.000 sampai Rp. 12.000.000, modal tetap ini menjadi modal yang sifatnya tahan lama dan menjadi pondasi pedagang UMKM mengoperasikan usahanya.

\section{Karakteristik responden berdasarkan modal operasional}

Sebelum mengetahui karakteristik responden berdasarkan modal operasional, terlebih dahulu dilakukan perhitungan skala interval modal operasioanl dengan modal opersioanl responden dari yang terkecil yaitu Rp. 200.000 sampai Rp. 2.000.000 Range dari Rp.200.000 ke Rp. 2.000.000 adalah Rp. 1.900.000. jika di penelitian ini menggunakan 4 kali interval, maka jarak setiap interval adalah Rp. $1.900 .000: 4=$ Rp.475.000. Artinya jarak interval ketagori modal operasional responden adalah Rp. 475.000

Tabel 10. Karakteristik responden berdasarkan modal operasional

\begin{tabular}{clcc}
\hline No & \multicolumn{1}{c}{ Modal operasional } & Frekuensi & Persentase (\%) \\
\hline 1 & Rp 200.000 - Rp 575.000 & 25 & 34,25 \\
2 & Rp. 675.000 - Rp. 1.050 .000 & 39 & 53,42 \\
3 & Rp. 1.150.000 -Rp. 1.525.000 & 8 & 10,96 \\
4 & Rp 1.625.000 - Rp. 2.000.000 & 1 & 1,37 \\
\hline & Jumlah & $\mathbf{7 3}$ & $\mathbf{1 0 0 , 0 0}$
\end{tabular}

Sumber : Data diolah 2020 
Dari Tabel 10 dapat dilihat bahwa pedagang UMKM di Pondok pesentren Kota Jambi yang modal operasionalnya berkisar Rp.200.000 sampai Rp. 575.000 sebanyak 25 orang pedagang dengan persentase sebesar 34,25 persen, kemudian jumlah pedagang yang modal operasionalnya diantara Rp. 675.000 sampai Rp.1.050.000 yaitu sebanyak 39 orang pedangang dengan persentase sebesar 53,42 persen, lalu jumlah pedagang yang modal operaionalnya diantara Rp. 1.150.000 sampai Rp. 1.525.000 yaitu sebanyak 8 orang dengan persentase sebesar 10,37 persen, sedangkan modal operasional berkisar Rp. 1.625 .000 - Rp. 2.000 .00 sebanyak 1 orang atau 1,37 persen. Modal operasional dengan jumlah pedagang paling banyak yaitu modal operasional yang berkisar Rp.675.000 sampai Rp.1.050.000. modal operasional tersebut banyak adalah modal yang dikeluarkan oleh unit usaha catering untuk membeli bahan jualan perharinya. Besar kecil modal operasioal dihitung berdasarkan rata-rata modal perhari untuk unit usaha catering yang dikeluarkan oleh pedagang dan rata-rata porsi yang terjual. Semakin besar modal operasional perhari menunjukan semakin besar pedapatan yang akan diterima pedagang.

\section{Karakteristik responden berdasarkan pendapatan}

Sebelum mengetahui karakteristik responden berdasarkan pendapatan, terlebih dahulu dilakukan perhitungan skala interval pendapatan dengan pendapatan responden dari yang terkecil yaitu Rp.1.000.000 sampai Rp. 15.000.000 Range dari Rp.1.000.000 ke Rp.15.000.000 adalah Rp. 15.000.000 jika di penelitian ini menggunakan 3 kali interval, maka jarak setiap interval adalah Rp. 15.000.000 : $3=$ Rp.5.000.000. Artinya jarak interval katagori pendapatan responden adalah Rp.5.000.000

Tabel 11. Karakteristik responden berdasarkan pendapatan

\begin{tabular}{cccc}
\hline No & Pendapatan & Frekuensi & Persentase (\%) \\
\hline 1 & Rp. 1.000.000 - Rp. 5.000.000 & 28 & 38,36 \\
2 & Rp. 6.000.000 - Rp. 10.000.000 & 36 & 49,31 \\
3 & Rp. 11.000.000 - Rp. 15.000.000 & 9 & 12,33 \\
\hline \multicolumn{2}{c}{ Jumlah } & $\mathbf{7 3}$ & $\mathbf{1 0 0 , 0 0}$
\end{tabular}

Sumber : Data diolah 2020

Dari Tabel 11 dapat dilihat bahwa pedagang UMKM di pondok pesentren Kota Jambi yang pendapatanya berkisar Rp. 1.000.000 sampai 5.000.000 perbulan sebanyak 28 orang pedagang dengan persentase 38,39 persen, kemudian jumlah pedagang yang pendapatanya diantara $\mathrm{Rp} 6.000 .000$ sampai dengan Rp. 10.000 .000 perbulan yaitu sebanyak 36 orang pedagang dengan persentase 49,31 persen, sedangkan pendapatan diantara Rp. 11.000.000 sampai Rp. 15.000 .000 perbulanya sebanyak 9 orang atau 12,33 persen. Pendapatan dengan jumlah pedagang paling banyak yaitu pendapatan yang berkisar Rp.6.000.000 sampai Rp. 10.000.000 perbulanya dengan jumlah pedagang sebanyak 26 orang. Pendapatan perbulan pedagang UMKM di pondok pesentren Kota Jambi dapat dikatakan besar dikarenakan unit usaha di pondok pesentren banyak. UMKM di pondok pesentren merupakan usaha yang menjanjikan untuk dikembangkan di pondok pesentren, bahkan 9 pedagang UMKM mendapat pendapatan bersih perbulanya sebesar Rp. 11.000.000 sampai Rp. 15.000 .000 perbulan. 


\section{Interprestasi hasil regresi linier berganda}

Berdasarkan analisis dengan program diolah dan diregres menggunakan software eviews 8, sehingga di dapatlah hasil estimasi sebagai berikut :

Tabel 13 Hasil uji regresi berganda

\begin{tabular}{lrlrr}
\hline \hline \multicolumn{1}{c}{ Variabel } & Coefficient & Std. Error & t-Statistic & Prob. \\
\hline \multicolumn{1}{c}{ C } & 3.037272 & 0.630331 & 4.818533 & 0.0000 \\
LOG(X1) Modal Tetap & 0.164504 & 0.057920 & 2.840222 & 0.0060 \\
LOG(X2) Modal Operasional & 0.443810 & 0.058775 & 7.551039 & 0.0000 \\
LOG(X3) Jam Kerja & -0.051843 & 0.015096 & -3.434327 & 0.0010 \\
LOG(X4) Lama Usaha & 0.001096 & 0.004985 & 0.219882 & 0.8266 \\
LOG(X5) Lokasi & 0.002911 & 0.008505 & 0.342297 & 0.7332 \\
\hline \hline & 0.510394 & Mean dependent var & 7.350548 \\
R-squared & 0.473856 & S.D. dependent var & 0.048185 \\
Adjusted R-squared & 0.034952 & Akaike info criterion & -3.791087 \\
S.E. of regression & 0.081848 & Schwarz criterion & -3.602830 \\
Sum squared resid & 144.3747 & Hannan-Quinn criter. & -3.716064 \\
Log likelihood & 13.96893 & Durbin-Watson stat & 1.918648 \\
F-statistic & 0.000000 & & & \\
Prob(F-statistic) & \multicolumn{4}{l}{} \\
\hline \hline
\end{tabular}

Sumber : Data diolah 2020

Berdasarkan Tebel di atas diperoleh persamaan regresi berganda sebagai berikut:

$$
\log Y=3.037+0.1645 \log X_{1}+0.4438 \log X_{2}-0.0518 X_{3}+0.0010 X_{4}+0.0029 \log X_{5}+e
$$

Persamaan Regresi tersebut mempunyai makna sebagai berikut :

Konstanta $=\mathbf{3 , 0 3 7}$

Jika variabel modal tetap, modal operasional, jam kerja, lama usaha, dan lokasi tetap atau tidak berubah, maka variabel pendapatan akan meningkat sebesar 3,037 persen.

\section{Koefisien modal tetap $\left(\mathrm{X}_{1}\right)=\mathbf{1 6 , 4 5}$}

Jika variabel modal tetap mengalami kenaikan sebesar satu persen, sementara modal operasional, jam kerja,lama usaha dan lokasi dianggap tetap atau tidak berubah, maka akan menyebabkan kenaikan pendapatan pedagang sebesar 16,45 Persen

\section{Koefisien modal operasional $\left(\mathrm{X}_{2}\right)=\mathbf{4 4 , 3 8}$}

Jika variabel modal operasional mengalami kenaikan sebesar satu persen, sementara modal tetap, jam kerja, lama usaha dan lokasi dianggap tetap atau tidak berubah, maka akan menyebabkan kenaikan pendapatan pedagang sebesar 44,38 persen.

\section{Koefisien jam kerja $\left(\mathbf{X}_{3}\right)=\mathbf{0 5}, 18$}

Jika variabel jam kerja mengalami kenaikan selama satu jam, sementara modal tetap, modal operasional, lama usaha dan lokasi dianggap tetap atau tidak berubah, maka akan menurunkan pendapatan pedagang sebesar 05,18 persen. 


\section{Koefisien lama usaha $\left(\mathbf{X}_{4}\right)=00,10$}

Jika variabel lama usaha mengalami kenaikan satu persen, sementara modal tetap, modal operasional, jam kerja dan lokasi dianggap tetap atau tidak berubah, maka akan menyebabkan kenaikan pendapatan pedagang sebesar 00,10 persen.

\section{Koefisien lokasi $\left(\mathbf{X}_{5}\right)=00,29$}

Jika Variabel lokasi mengalami kenaikan sebesar satu persen, sementara modal tetap, modal operasional, jam kerja dan lama usaha dianggap tetap atau tidak berubah maka akan menyebabkan kenaikan pendapatan pedagang sebesar 00,29 persen.

\section{Pengujian hipotesis secara simultan (Uji F)}

Uji $\mathrm{F}$ dilakukan untuk melihat pengaruh variabel independen secara simultan terhadap variabel dependen atau sering disebut uji kelinieran persamaan regresi. Hasil dari uji $\mathrm{F}$ pada penelitian ini diperoleh nilai sig $=0,000<0,05$ ini bearti variabel independen modal tetap, modal operasional, jam kerja, lama usaha dan lokasi secara simulutan benar-benar berpengaruh signifikan terhadap variabel dependen pendapatan pedagang UMKM di pondok pesentren Kota Jambi. Maka dengan kata lain variabelvariabel modal tetap, modal operasional, jam kerja, lama usaha, dan lokasi mampu menjelaskan besarnya variabel dependen pendapatan pedagang UMKM pondok pesentren.

\section{Pengujian hipotesis secara persial (uji t)}

Uji t dilakukan untuk mengetahui apakah secara individu (persial) variabel independen mempengaruhi variabel dependen secara signifikan atau tidak. Jika tingkat signifikan dibawah 5\% maka secara persial modal tetap, modal operasional, jam kerja, lama usaha dan lokasi berpengaruh terhadap pendapatan pedagang UMKM pondok pesentren.

Maka dengan tingkat kepercayaan $=95 \%$ atau $(\alpha)=0,05$. Derajat kebebsan $(\mathrm{df})$ $=\mathrm{n}-\mathrm{k}-1=73-5-1=67$, serta pengujian dua sisi diperoleh dari nilai t 0,05 $=1.667$.

\section{Variabel modal tetap $\left(\mathbf{X}_{1}\right)$}

Dari hasil pengujian diperoleh nilai $t_{\text {hitung }}$ untuk variabel modal tetap sebesar 2.840222dengan tingkat keyakinan $(\alpha=5 \%)$ df (68) untuk pengujian diperoleh nilai $t_{\text {tabel }} 1,667$ dari perhitungan tersebut dapat dilihat bahwa nilai $t_{\text {hitung }}$ lebih besar dari $t_{\text {tabel }}$ (2.840222> 1,667), artinya Ho ditolak dan Ha diterima artinya modal tetap berpengaruh signifikan dan positif terhadap pendapatan pedagang UMKM pondok pesentren Kota Jambi. Dengan demikian hipotesis yang menyatakan pengaruh modal tetap terhadap pendapatan pedagang di pondok pesentren Kota Jambi tahun 2020 benar dan terbukti.

\section{Variabel modal operasional $\left(\mathbf{X}_{2}\right)$}

Dari hasil pengujian diperoleh nilai thitung untuk variabel modal operasional sebesar 7.551039 dengan tingkat keyakinan $(\alpha=5 \%)$ df (68) untuk pengujian diperoleh nilai $t_{\text {tabel }} 1,667$ dari perhitungan tersebut dapat dilihat bahwa nilai $t_{\text {hitung }}$ lebih besar dari $t_{\text {tabel }}(7.551039>1,667)$, artinya Ho ditolak dan Ha diterima artinya modal operasional berpengaruh signifikan dan positif terhadap pendapatan pedagang UMKM pondok pesentren Kota Jambi. Dengan demikian hipotesis yang menyatakan pengaruh modal operasional terhadap pendapatan pedagang di pondok pesentren Kota Jambi tahun 2020 benar dan terbukti. 


\section{Variabel jam kerja $\left(\mathbf{X}_{3}\right)$}

Dari hasil pengujian diperoleh nilai thitung untuk variabel jam kerja sebesar 3.434327 dengan tingkat keyakinan $(\alpha=5 \%)$ df (68) untuk pengujian diperoleh nilai $\mathrm{t}_{\text {tabel }} 1,667$ dari perhitungan tersebut dapat dilihat bahwa nilai $t_{\text {hitung }}$ lebih besar dari $t_{\text {tabel }}$ $(-3.434327>1,667)$, artinya Ho ditolak dan Ha diterima artinya jam kerja terpengaruh signifikan dan positif terhadap pendapatan pedagang UMKM pondok pesentren Kota Jambi. Dengan demikian hipotesis yang menyatakan pengaruh jam kerja terhadap pendapatan pedagang UMKM pondok pesantren Kota Jambi tahun 2020 benar dan terbukti.

\section{Variabel lama usaha $\left(\mathbf{X}_{4}\right)$}

Dari hasil pengujian diperoleh nilai $t_{\text {hitung }}$ untuk variabel lama usaha sebesar 0.219882 dengan tingkat keyakinan $(\alpha=5 \%)$ df (68) untuk pengujian diperoleh nilai $t_{\text {tabel }} 1,667$ dari perhitungan tersebut dapat dilihat bahwa nilai $t_{\text {hitung }}$ lebih kecil dari $t_{\text {tabel }}$ $(0.219882>1,667)$, artinya Ho diterima dan Ha ditolak artinya lama usaha tidak berpengaruh signifikan dan positif terhadap pendapatan pedagang UMKM pondok pesentren Kota Jambi. Dengan demikian hipotesis yang menyatakan pengaruh lama usaha terhadap pendapatan pedagang UMKM pondok pesantren di Kota Jambi tahun 2020 tidak benar dan tidak terbukti.

\section{Variabel lokasi $\left(\mathbf{X}_{5}\right)$}

Dari hasil pengujian diperoleh nilai $t_{\text {hitung }}$ untuk variabel lokasi sebesar 0.342297 dengan tingkat keyakinan ( $\alpha=5 \%$ ) df (68) untuk pengujian diperoleh nilai $t_{\text {tabel }} 1,667$ dari perhitungan tersebut dapat dilihat bahwa nilai thitung lebih kecil dari tabel $(0.342297$ $>1,667)$, artinya Ho diterima dan Ha ditolak artinya lokasi tidak berpengaruh signifikan dan positif terhadap pendapatan pedagang UMKM pondok pesentren di Kota Jambi. Dengan demikian hipotesis yang menyatakan pengaruh lokasi terhadap pendapatan pedagang UMKM pondok pesantren di Kota Jambi tahun 2020 tidak benar dan tidak terbukti.

\section{Koefisien determinasi $\left(\mathbf{R}^{2}\right)$}

Dari hasil perhitungan secara statistik dengan menggunakan Eviews 8 diperoleh nilai koefisien determinasi $\mathrm{R}^{2}$ sebesar 0,51 atau $51 \%$. Hal ini bearti $51 \%$ dari variasi pendapatan pedagang UMKM pondok pesntren di Kota Jambi dijelaskan oleh variabel bebas dalam model, sedangkan $49 \%$ dijelaskan oleh variabel lain diluar penelitian.

\section{Pengujian asumsi klasik}

Model yang dihasilkan sebelum digunakan untuk pengujian hipotesis, maka dilakukan pengujian dengan uji asumsi klasik untuk mendapatkan model yang "blues" atau "best fit model".

\section{Normalitas data}

Untuk mendeteksi apakah data terdistribusi normal atau tidak di dalam model penelitian menggunakan metode probability. Keputusan terdistribusi normal tidaknya residual secara sederhana dengan membandingkan nilai probabilityhitung dengan tingkat alpha 0,05 (5\%). Apabila probabilityhitung lebih besar dari 0,05 maka dapat disimpulkan bahwa residualterdistribusi normal dan sebaliknya, apabila nilainya lebih kecil maka tidak cukup buktiuntuk menyatakan bahwa residual terdistribusi normal. 


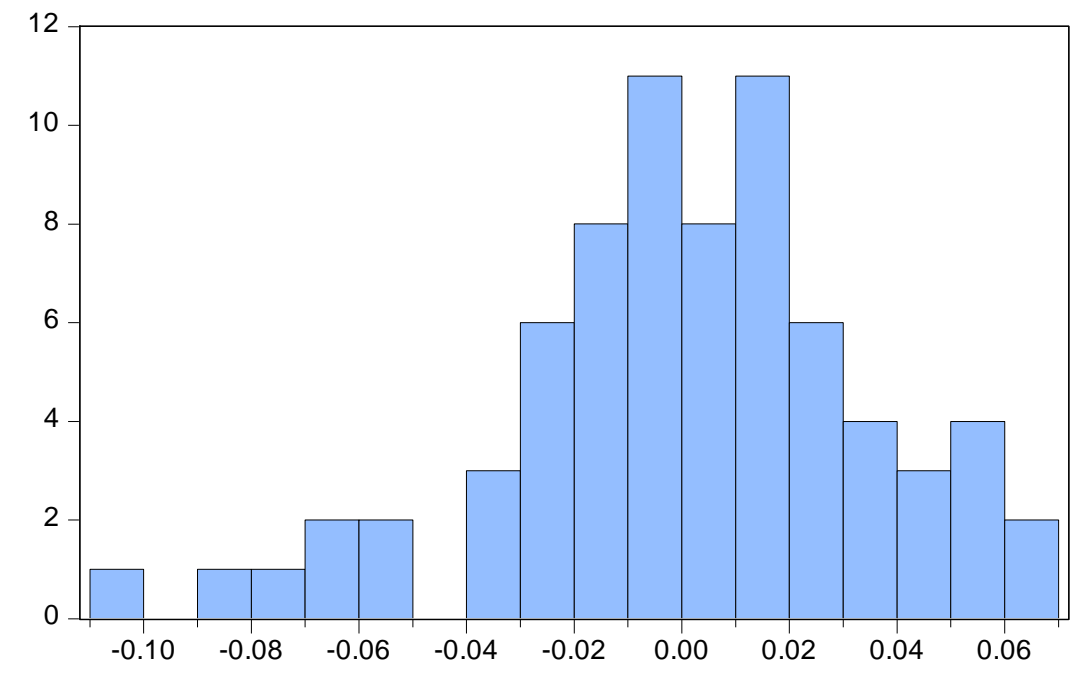

\begin{tabular}{lr} 
Series: Residuals \\
Sample 1 73 \\
Observations 73 \\
Mean & $-2.96 \mathrm{e}-16$ \\
Median & 0.000681 \\
Maximum & 0.064220 \\
Minimum & -0.107751 \\
Std. Dev. & 0.034441 \\
Skewness & -0.574314 \\
Kurtosis & 3.596596 \\
& \\
Jarque-Bera & 5.095620 \\
Probability & 0.078253 \\
\hline
\end{tabular}

Gambar 1 Uji Normalitas

Berdasarkan Gambar 5.1. Hasil pengolahan dapat dilihat Nilai Probability hitung sebesar 0,07>0,05 sehingga dapat disimpulkan bahwa residual terdistribusi normal.

\section{Uji multikolinieritas}

Uji multikolinieritsas bertujuan untuk menguji apakah dalam model regresi ditemukan adanya kolerasi antar variabel bebas. Model regresi yang tinggi tidak terjadi kolerasi antar variabel bebas. Untuk mendeteksi ada tidaknya multikolinieritas di dalam model regresi adalah dengan melihat nilai toleransi dan Variance Inflation Factor (VIF). Apabila nilai tolerance $>10 \%$ dan nilai VIF $<10$, maka dapat disimpulkan tidak ada multikolinieritas antar variabel bebas dalam model regresi.

Tabel 12 Uji Multikolinieritas

\begin{tabular}{cccc}
\hline \hline Variabel & $\begin{array}{c}\text { Coefficient } \\
\text { variance }\end{array}$ & $\begin{array}{c}\text { Uncentered } \\
\text { VIF }\end{array}$ & $\begin{array}{c}\text { Centered } \\
\text { VIF }\end{array}$ \\
\hline C & 0.397317 & 23742.47 & NA \\
LOG(X1) & 0.003355 & 11007.72 & 1.017531 \\
LOG(X2) & 0.003454 & 10704.04 & 1.057957 \\
LOG(X3) & 0.000228 & 58.48685 & 1.027606 \\
LOG(X4) & $2.49 \mathrm{E}-05$ & 4.992796 & 1.071341 \\
LOG(X5) & $7.23 \mathrm{E}-05$ & 6.744175 & 1.037689 \\
\hline \hline
\end{tabular}

Sumber : Data diolah 2020

Berdasarkan Tabel 12 terlihat setiap variabel bebas mempunyai nilai tolerance > 0,1 dan nilai VIF $<10$. Jadi dapat disimpulkan bahwa tidak ada multikolinieritas antar variabel bebas dalam model regresi ini.

\section{Uji autokorelasi}

Autokolerasi didefinisikan sebagai kolerasi/keterkaitan antara serangkaian observasi yang diurutkanmenurut waktu dan ruang. Untuk mengetahui ada atau tidaknya gejaka autokolerasi dalam perhitungan regresi atas penelitian ini maka digunakan Durbin-Watson Test sebesar 1.859494 
Dengan mengunakan tabel stastistik d dan derajat kepercayaan 95\% $(\alpha=0,05)$ jumlah observasi 73 serta jumlah variabel bebas 5 maka diperoleh $\mathrm{dl}=1,340 \mathrm{dan} \mathrm{du}+$ 1,617 sedangkan nilai untuk 4-dl = 2,660 dan 4-du =2,383 dengan menggunakan uji statistic Durbin Waston dua ujung two tailend) maka patokan yang digunakan adalah sebagai berikut: 1). Jika $\mathrm{d}<\mathrm{dl}=$ bearti terdapat autokolerasi positif , 2). Jika $\mathrm{d}>\mathrm{dU}=$ bearti tidak terdapat autokolerasi positif, 3). Jika (4-d) $<\mathrm{dl}=$ bearti terdapat autokolerasi negative, 4). Jika (4-d) $>d U$ = bearti tidak terdapat autokolerasi negative, 5). Jika $d u<d$ $<(4-\mathrm{du})=$ bearti tidak terdapat autokolerasi, 6). Jika $\mathrm{dl}<\mathrm{d}<\mathrm{du}$ atau $(4-\mathrm{du})=$ bearti tidak dapat disimpulkan hasil yang diperoleh adalah nilai DW observasi terletak pada daerah $(\mathrm{d}>\mathrm{dU}$ bearti tidak terdapat autokolerasi positif dalam penelitian ini.

\section{Uji heterokedasitas}

Salah satu cara untuk mengetahui ada tidaknya heteroskedastisitas pada suatu model dapat menggunakan ujiBreusch-Pagan-Godfrey. Keputusan terjadi atau tidaknya heteroskedastisitas pada model regresi linier adalah dengan melihat Nilai Prob. ChiSquare(5).Apabila nilai Prob. Chi-Square(5)lebih besardari tingkat alpha 0,05 (5\%) artinya tidak terjadi heteroskedastisitas,sedangkan apabilanilai Prob. ChiSquare(5).lebih kecil dari dari tingkat alpha 0,05 (5\%) maka terjadi heteroskedastisitas.

Tabel 13. Heteroskedastisitas

Heteroskedasticity Test: Breusch-Pagan-Godfrey

\begin{tabular}{llll} 
F-statistic & 0.380825 & Prob. F(5,67) & 0.8602 \\
Obs*R-squared & 2.017313 & Prob. Chi-Square(5) & 0.8467 \\
Scaled explained SS & 2.188924 & Prob. Chi-Square(5) & 0.8224 \\
\hline
\end{tabular}

Sumber : Data diolah 2020

Berdasarkan Tabel 13 dapat dilihat bahwa nilai Prob. Chi-Square(5)sebesar 0.8224lebih besar dari tingkat alpha 0,05 (5\%) sehingga, dapat disimpulkan tidak terjadi gejala heroskedastisitas dalam model regresi.

\section{Analisis SWOT}

Strategi pengembangan UMKM pondok Pesantren Kota Jambi diarahkan melalui analisis SWOT. Analisis SWOT yang terdiri dair 4 alternatif antara lain strategi S-O (Strategi opportunities), Strategi S-T (strength-threat), strategi W-O (weakness opportunities) dan strategi WT (weakness-threat) yaitu suatu metode analisis yang menggambarkan kekuatan, kelemahan, peluang dan ancaman, serta kendala-kendala yang harus dihadapi selama proses perencanaan.

Kekuatan yang ada, disamping ada kelemahan, maka mampu mengurangi kelemhan yang ada dan saat yang sama memaksimumkan kekuatan. Hal ini akan berlangsung pada tantangan dan peluang dimana pada saat tantangan dapat diperkecil, peluang yang ada justru diperbesar. Kondisi yang dihadapi dalam pengembangan UMKM di pondok pesentren di Kota Jambi meliputi kondisi internal dan eksternal yaitu

\section{Analisis kondisi internal}

\section{Kekuatan (Strengts)}

1. Lokasi usah yang strategis

2. Pelayanan kepada pelanggan yang bersifat kekeluargaan

3. Harga yang bersaing 
4. Jam operasional yang panjang

5. Hubungan yang baik dengan pemasok bahan baku

6. Banyak unit usaha yang ditawarkan

7. Sumber daya manusia yang mempuni

Kelemahan (Weaknesses)

1. Sumberdaya keungan yang masih terbatas

2. Promosi yang kurang maksimal

3. Keterampilan pekerjaan belum sama

4. Harga bahan baku yang fluktuatif

5. Teknologi dalam kegiatan produksi masih sederhana

6. Belum adanya program pembinaan dari pemerintah

7. Terbatasnya akses pada lembaga keuangan

\section{Analisis Kondisi Ekternal}

\section{Peluang (Opportunity)}

1. Mempunyai konsumen tetap

2. Adanya sarana dan prasarana yang cukup, walaupun belum lengkap

3. Adanya modal yang dapat digunakan untuk biaya pengembangan

4. Banyak menyerap tenaga kerja

5. Sarana dalam pendistribusian produk-produk industri besar

6. Peneriman produk oleh semua lapisan masyarakat

7. Tidak adanya pesaing yang berarti

\section{Ancaman (Threats)}

1. Menjamurnya usaha usaha baru

2. Bunga pinjaman bank yang tinggi

3. Harga bahan baku yang tinggi

4. Belum adanya takaran yang baku atasa satu jenis produk

5. Persaingan dengan usaha sejenis

6. Kurang optimalisasi waktu pengembangan, dikarenakan ada aktivitas lain yang harus ditunaikan Kebijakan pemerintah yang belum berpihak pada usaha kecil

\section{KESIMPULAN DAN SARAN}

\section{Kesimpulan}

Berdasarkan hasil karakteristik social ekonomi pedagang UMKM dapat disumpulkan rata-rata umur pedagang usaha berkisar empat puluh delapan tahun, ratarata Jumlah anak pedagang UMKM berkisar dua orang anak, rata-rata jumlah tangunggan pedagang UMKM berkisar kurang dari tiga tangunggan, rata-rata tingkat pendidikan pedagang UMKM yaitu strata satu sampai strata dua, rata-rata jam kerja pedagang UMKM pondok pesentren Kota Jambi selama tujuh jam bekerja, rata-rata lama usaha pedagang selama lima tahun bekerja, rata-rata pedagang berjualan di tempat strategis, rata-rata omset perhari sebesar sembilan ratus lima puluh ribu rupiah. rata-rata modal tetap pedagang mendirikan usahanya sebesar dua belas juta sembilan ratus tiga puluh lima ribu rupiah rata-rata modal operasional pedagang sebesar enam ratus tujuh puluh tujuh ribu rupiah dan rata-rata pendapatan usaha UMKM pondok pesentren Kota Jambi enam juta enam ratus delapan ribu rupiah.

Berdasarkan Hasil dari uji F pada penelitian ini diperoleh nilai sig $=0,000<0,05$ ini bearti variable secara simultan benar-benar berpengaruh signifikan terhadap variable dependen pendapatan pedagang UMKM di pondok pesentren Kota Jambi. Dengan 
mengunakan uji t untuk mengetahui secara persial pengaruh variabel independen terhadap variabel dependen dapat disimpulkan bahwa variabel modal tetap, modal operasional dan jam kerja berpengaruh signifikan terhadap pendapatan pedagang UMKM pondok pesentren sedangkan variabel lama usaha dan lokasi tidak berpengaruh signifikan terhadap pendapatan pedagang umkm di pondok pesentren, besarnya kontribusi variabel Modal tetap, modal operasional, jam kerja, lama usaha dan lokasi dapat dilihat pada koefisien determinasi $\left(\mathrm{R}^{2}\right)$ sebesar 0,51 atau $51 \%$ dari pendapatan pedagang dipengaruhi oleh variabel bebas sedangkan sisanya $49 \%$ dipengaruhi oleh variabel lain yg tidak dimasukan dalam model atau penelitian ini.

Dari hasil matriks SWOT dibagi menjadi strategi S-O, Strategi W-O, Strartegi ST dan Strategi W-T, Strategi S-O yaitu mengembangkan Melakukan Focus Group Discussion, dan analisis masalah dengan Penanggung Jawab sektor Unit-Unit Usaha. Kegiatan ini dilakukan guna mencari permasalahan dan menemukan potensi Unit-Unit Usaha di pondok pesentren Kota Jambi, strategi W-O yaitu melakukan promosi yang lebih baik untuk menarik konsumen baru, meningkatkan keahlian para pekerja dalam kegiatan usaha, strategi S-T yaitu mempertahankan hubungan kerjasama yang baik dengan pemasok bahan baku, pinjaman modal kerja kepada pelaku usaha kecil dengan bunga ringan dan menawarkan variasi unit usaha yang baru dipendok pesentren, pembinaan terhadap kemampuan manajerial dari pemerintah merupakan strategi $\mathrm{W}-\mathrm{T}$ yang cukup efektif untuk diterapkan.

\section{Saran}

Berdasarkan kesimpulan diatas, maka dapat diberikan masukan-masukan berupa saran yaitu: Untuk meningkatkan pendapatan pedagang UMKM maka kebijakan yang dapat diambil yaitu memaksimalkan modal operasional agar lebih efektif dan efisien, sehingga modal operasional yang dikeluarkan oleh pedagang dapat menghasilkan output yang maksimal sehingga akan berdampak terhadap peningkatan pendapatan.

\section{DAFTAR PUSTAKA}

Agusry, Ferdiananda. (2006). Metode penelitian manajemen pedoman penelitan untuk tesis dan disertas ilmu manajemen, Universitas Diponogoro: Semarang.

Al- Hamdani.(2006). Manajemen pemasaran jasa, Edisi Kedua, Salemba Empat: Jakarta

Asruni. (2012). Faktor-faktor yang mempengaruhi pendapatan usaha kecil dan menengah (UKM) di Kabupaten Hulu Sungai Selatan Provinsi Kalimantan Selatan, Jurnal 17 Kindai, 2012(8), 362-380:

Budiono. (2000). Ekonomi moneter, Edisi Ketiga : BPFE : Yogyakarta.

Budiono . (2002). Pengantar ekonomi mikro, PT. Raja Grapindo Persada: Jakarta

Bygrave.W.D. (2004). The portable MBA in entrepreneurship. NB: Jhon Wiley dan Sons: Hoboken

Dwiangga R, Tegar. (2013). Analisis yang mempengaruhi pendapatan pemilik usaha dan tenaga kerja pada industri berskala kecil di Kota Kediri. Jurnal Ilmiah Mahasiswa FEB Universitas Brawijaya, 1(2), 1-10

Farhan, Muhammad. (2013). Analisis data penelitian dengan statistik. Bumi Aksara: Jakarta

Gujarati, Damodar. Sumarno Zain; penterjemah. (2003). Ekonometrika dasar. CetakanPertama. Erlangga: Jakarta.

Hamel dan Prahal. (1995). Management. Tata Mc Grow Hill: New Delhi

Kasal, Rhenald. (2010). Wirausaha muda mandiri. PT Gramedia Pustaka: Jakarta 